\title{
Electroconvulsive Seizure Treatment Increases Cell Proliferation in Rat Frontal Cortex
}

\author{
Torsten M Madsen', Damaris D Yeh', Gerald W Valentine' and Ronald S Duman*,' \\ 'Laboratory of Molecular Psychiatry, Departments of Psychiatry and Pharmacology, Yale University School of Medicine, New Haven, CT, USA
}

\begin{abstract}
Recent studies have demonstrated increased neurogenesis in adult hippocampus in response to electroconvulsive seizure (ECS) or antidepressant drug treatment. Adult neurogenesis in the subgranular zone of the hippocampus and the subventricular zone is well established, whereas neuronal proliferation outside of these areas under unstimulated conditions is not observed. Since mood disorders are likely to involve brain regions in addition to hippocampus, particularly the frontal cortex, it is likely that antidepressant treatments produce cellular changes in these brain regions as well. In this study, we have investigated the effect of repeated ECS administration on the proliferation of cells in the frontal cortex, and we have examined the phenotype of these cells 4 weeks after labeling with a cell division marker. We found that ECS treatment increases the number of newly divided cells in the frontal cortex and that these new cells express markers of either endothelial cells or oligodendrocytes, but not neurons. It is possible that increased proliferation of these cell types in the frontal cortex could reverse the loss of glial cell number and the reduced volume that has been reported in the frontal cortex of depressed patients.
\end{abstract}

Neuropsychopharmacology (2005) 30, 27-34, advance online publication, 22 September 2004; doi: I 0. I038/sj.npp. I 300565

Keywords: affective disorders; depression; immunohistochemistry; glia; endothelial cells

\section{INTRODUCTION}

In the mammalian brain, adult neurogenesis has been documented to occur primarily in two regions, the subgranular zone (SGZ) of the hippocampus and the subventricular zone (SVZ), the cell layer immediately below the ependyma in the medial portion of the lateral ventricles. The neurons formed in the SGZ migrate into the granule cell layer, extend processes, and mature into neurons that are virtually indistinguishable from existing granule cells. Neurons in the SVZ migrate to the olfactory bulb and become mature granule cells (Markakis and Gage, 1999; van Praag et al, 2002).

The process of hippocampal neurogenesis is subject to regulation by a number of factors. This includes environmental factors such as stress that reduces neurogenesis (Gould et al, 1998), physical activity that increases neurogenesis (van Praag et al, 1999), as well as genetic factors (Kempermann et al, 1997). In the hippocampus, neurogenesis is also regulated by the administration of

\footnotetext{
*Correspondence: Dr RS Duman, Laboratory of Molecular Psychiatry, Departments of Psychiatry and Pharmacology, Yale University School of Medicine, 34 Park Street, New Haven, CT, USA,

Tel: + I 203974 7726, Fax: + I 203974 7724,

E-mail: ronald.duman@yale.edu

Received 6 April 2004; revised 19 July 2004; accepted 4 August 2004 Online publication: 12 August 2004 at http://www.acnp.org/citations/ Npp08120404/57/default.pdf
}

chemical antidepressants (Malberg et al, 2000). Seizure activity, including electroconvulsive seizures (ECS), a model for electroconvulsive therapy, also dramatically increases neurogenesis in the SGZ of the hippocampus (Madsen et al, 2000; Scott et al, 2000). The dynamic regulation of neurogenesis in the hippocampus, together with human studies showing volume changes in this region in mood disorders (Bremner et al, 1999; Sheline et al, 1999), suggests a link between reduced neurogenesis and depression, and conversely, increased neurogenesis in the action of antidepressant treatment (see Duman et al, 2001; Jacobs, et al, 2000).

In addition to alterations in the morphology of the hippocampus, brain imaging and post-mortem studies have reported atrophy and cell loss in the frontal cortex of depressed patients (Duman et al, 2001; Manji et al, 2001; Nestler et al, 2002). Of particular interest to the current study are post-mortem studies that have demonstrated decreased number of glia and reduced size of neuronal cell bodies in the subgenual and dorsal lateral prefrontal cortex, as well as the cingulate cortex in depressed patients (Ongur et al, 1998; Rajkowska et al, 1999; Cotter et al, 2001). The reduction in the number of glia and the size of neuronal cell bodies could contribute to the decrease in volume of subgenual prefrontal cortex reported in depression (Drevets et al, 1997). These findings have led to hypotheses of affective disorders being accompanied by glial cell dysfunction (Coyle and Schwarcz, 2000). 
While neurogenesis in the adult mammalian brain outside of the SVZ and SGZ has been reported (Gould et al, 1999), this observation has not been confirmed by other groups (Koketsu et al, 2003; Kornack and Rakic, 2001). Neurogenesis can occur in cortical regions upon a given insult, such as ischemia (Arvidsson et al, 2002) or lesions (Magavi et al, 2000). Also, intracerebroventricular infusion of growth factors such as brain-derived neurotrophic factor (BDNF) causes proliferation and neurogenesis in the striatum and neocortex (Pencea et al, 2001). Interestingly, progenitor cells that are capable of later differentiating into glia or neurons can be isolated and cultured from all parts of the mammalian brain (Palmer et al, 1995). This indicates that outside of the primary neurogenic zones, the SGZ and SVZ, progenitor cells with the potential to differentiate into neurons are present, but that under normal conditions the factors needed to promote neurogenesis are not present.

ECS is a potent treatment for major depression, usually considered for patients who fail to respond to chemical antidepressants. In this study, we extend previous work on ECS by investigating the effects of repeated ECS on the proliferation of cells in the frontal cortex. Further, we attempt to characterize the phenotype of the cells proliferating in this region.

\section{MATERIALS AND METHODS}

\section{Animals and ECS Administration}

Male Sprague-Dawley rats (Charles River, MA) weighing 175-225 $\mathrm{g}$ at the beginning of the experiments were housed under standard conditions with free access to lab chow and water. All procedures were in full accordance with Yale University care and use of laboratory animals (YACUC) guidelines.

Animals were given repeated seizures (once daily for 10 days) $(55 \mathrm{~mA}, 0.3 \mathrm{~s})$ via earclip electrodes. This treatment consistently elicits a generalized seizure throughout the treatment period as reported previously (Chen et al, 2001). Control animals received similar handling and had earclips mounted but no current was passed. There were five and six animals, respectively, for the sham and ECS treatment groups.

\section{Bromodeoxyuridine (BrdU) Administration}

BrdU (Sigma, St Louis, MO) was administered by i.p. injections of a $15 \mathrm{mg} / \mathrm{ml}$ solution, dissolved by gentle warming to $37^{\circ} \mathrm{C}$ in a water bath. BrdU was administered as a single injection $(100 \mathrm{mg} / \mathrm{kg}) 6 \mathrm{~h}$ after the last ECS. These animals ( $n=5$ and 6 for sham and ECS treatment groups) were used for phenotype studies, and survived 28 days after the last injection. Another set of animals was given three injections of BrdU $(100 \mathrm{mg} / \mathrm{kg})$ on the last 3 days of the ECS treatment. Injections were administered $6 \mathrm{~h}$ after the ECS on each of the last 3 days. These animals $(n=5$ and 6 for sham and ECS treatment, respectively) were killed $2 \mathrm{~h}$ after the last BrdU injection and were used for studies of cell proliferation.

\section{Tissue Processing}

Animals were subjected to transcardial perfusion in ice-cold phosphate-buffered saline (PBS) followed by $4 \%$ paraformaldehyde and overnight postfixation. The brains were equilibrated in $30 \%$ sucrose, cut into $40 \mu \mathrm{m}$ thick coronal sections on a freezing microtome, and kept at $-20^{\circ} \mathrm{C}$ in a cryoprotectant solution until immunostaining. For every animal, sections were prepared in a one in 10 series, so that every 10th section of the frontal cortex was processed simultaneously.

\section{Immunostaining}

Sections were washed in potassium PBS (KPBS) prior to incubation in $2 \mathrm{~N} \mathrm{HCl}$ at $37^{\circ} \mathrm{C}$ for $20 \mathrm{~min}$. Then sections were blocked in KPBS containing 0.3\% Triton X-100 (KPBS$\mathrm{T}$ ) and $3 \%$ normal goat serum (Jackson Immunoresearch, $\mathrm{PA})$ for $1 \mathrm{~h}$. The sections were then incubated in a mix of primary antibodies (see below) in the blocking buffer for 3 days at $4^{\circ} \mathrm{C}$. Following washes in KPBS, fluorescent-labeled secondary antibodies (Alexa 488, 546 or 633, Molecular Probes, OR) were added at a concentration of 1:200 in blocking buffer for $1 \mathrm{~h}$ at room temperature. Sections were mounted, dried, and coverslipped in Gelmount (Biomeda, CA).

\section{BrdU-Immunoperoxidase Staining}

Brains from all animals of sham- and ECS-treated groups were processed in parallel. Sections were stained in a freefloating procedure and initially washed $(3 \times 10 \mathrm{~min})$ in KPBS. Then, the sections were transferred to a solution of $50 \%$ formamide in $2 \times \mathrm{SSC}$ for $2 \mathrm{~h}$ at $65^{\circ} \mathrm{C}$. After three washes in $\mathrm{KPBS}$, they were incubated in $2 \mathrm{~N} \mathrm{HCl}$ at $37^{\circ} \mathrm{C}$ for $30 \mathrm{~min}$. Sections were again washed in KPBS followed by incubation in blocking buffer (KPBS containing $0.25 \%$ Triton X-100 and 3\% normal horse serum for $1 \mathrm{~h}$ ). The sections were then transferred to primary antibody solution (mouse anti-BrdU, 1:100, BD Transduction Labs, Los Angeles, CA) in blocking buffer overnight at $4^{\circ} \mathrm{C}$. After washing sections in KPBS, the secondary antibody was applied (horse anti-mouse, BA 2001, Vector, Burlingame, CA). Sections were then processed for visualization of the labeled cells using the $\mathrm{ABC}$ elite kit according to the manufacturer's specifications (Vector, Burlingame, CA). The bound complexes were then visualized with diaminobenzidine (Vector, Burlingame, CA), mounted, dried, counterstained in vector fast red (Vector, Burlingame, CA), and coverslipped.

\section{Antibodies Used for Cellular Phenotyping}

There were several different antibodies used for double labeling to characterize the phenotype of BrdU-labeled cells. This included rat anti-BrdU (Accurate Chemicals, Westbury, NY) 1:100, mouse anti-NeuN (Chemicon, Temecula, CA) 1:100, mouse anti-Rip (developed by Susan Hockfield, obtained from Developmental Studies Hybridoma Bank, University of Iowa, IO) (Friedman et al, 1989), monoclonal mouse anti-rat endothelial cell antigen (RECA-1, Serotec, Oxford, UK)(Duivestijn et al, 1992), mouse anti-glial 
fibrillary acidic protein (GFAP, 1:500) (Sigma, St Louis, $\mathrm{MO}$ ), and anti-S100 $\beta$ (1:500, Rabbit polyclonal, Sigma, St Louis, MO).

\section{Quantification of BrdU Single- and Double-Labeled Cells}

The number of BrdU-labeled cells in the caudal two-thirds of the medial prefrontal cortex (mPFC) was determined using a modified unbiased stereology method and Stereo Investigator software (MicroBrightField, Williston, VT). The definition of the mPFC in rat is based on several criteria including connectional, cytoarchitectural, neurochemical, and functional considerations (Van Eden and Uylings, 1985; Uylings et al, 2003). The caudal two-thirds of the mPFC was chosen for analysis because it contains regions implicated in human depression and because it also provides large reference spaces that can be unambiguously defined.

Every 10th section from Paxinos and Watson (1998) coordinates 3.70 to $1.70 \mathrm{~mm}$ relative to Bregma were analyzed from each animal. These sections corresponded approximately to plates $7,8,9,10$, and 11 . Using Stereo Investigator software, plate-specific contours within the mPFC were used to define consistent, bounded reference spaces within each brain section used in the analysis (Figure 1). In most cases, the exact same contour for a given plate could be used between hemi-sections of the same animal. Often, the same contour was used between animals with only minor modifications. Importantly, the contour corresponding to a given plate was always of the same total area for each animal. Therefore, the total area of the reference space within the mPFC sampled for a given plate was the same between animals and, therefore, between experimental and control groups. The total area per section ranged from $2.3 \times 10^{6} \mu \mathrm{m}^{2}$ to $3.5 \times 10^{6} \mu \mathrm{m}^{2}$ with the lowest being plate 11 and the highest plate 9 (see Figure 1). Brain regions included in this analysis were infralimbic, prelimbic, and cingulate cortex. In plates 9 and 10, a small portion of the dorsal peduncular cortex was also included. All contours were drawn as to exclude white matter within the corpus callosum.

This sampling was determined to be adequate based on analysis of 10 hemi-sections per animal, and using an average of 620 randomly and systematically placed dissectors per animal. Based on our calculations of the coefficients of variation and mean coefficient of error, we determined that this sampling is adequate. For the ECS group, $83 \%$ of the observed variance was due to biological variation and $17 \%$ due to sampling error. For the control group, $80 \%$ of the observed variance was due to biological variation and $20 \%$ due to sampling error. As the sampling error was less than half that of the biological variability, we feel that our sampling scheme was appropriate for reliably detecting differences in BrdU labeling between groups.

A fractionator probe was then used to estimate the number of labeled cells that were contained within each reference space of the caudal mPFC. This allowed for quantitation of BrdU-labeled cells using a systematic and random sampling of $\mathrm{mPFC}$. The fractionator was designed to sample $50 \%$ of the reference space. Quantitation was performed at a magnification of $400 \times$ using a $175 \times 175 \mu \mathrm{m}^{2}$ counting frame with a distance of $250 \mu \mathrm{m}$
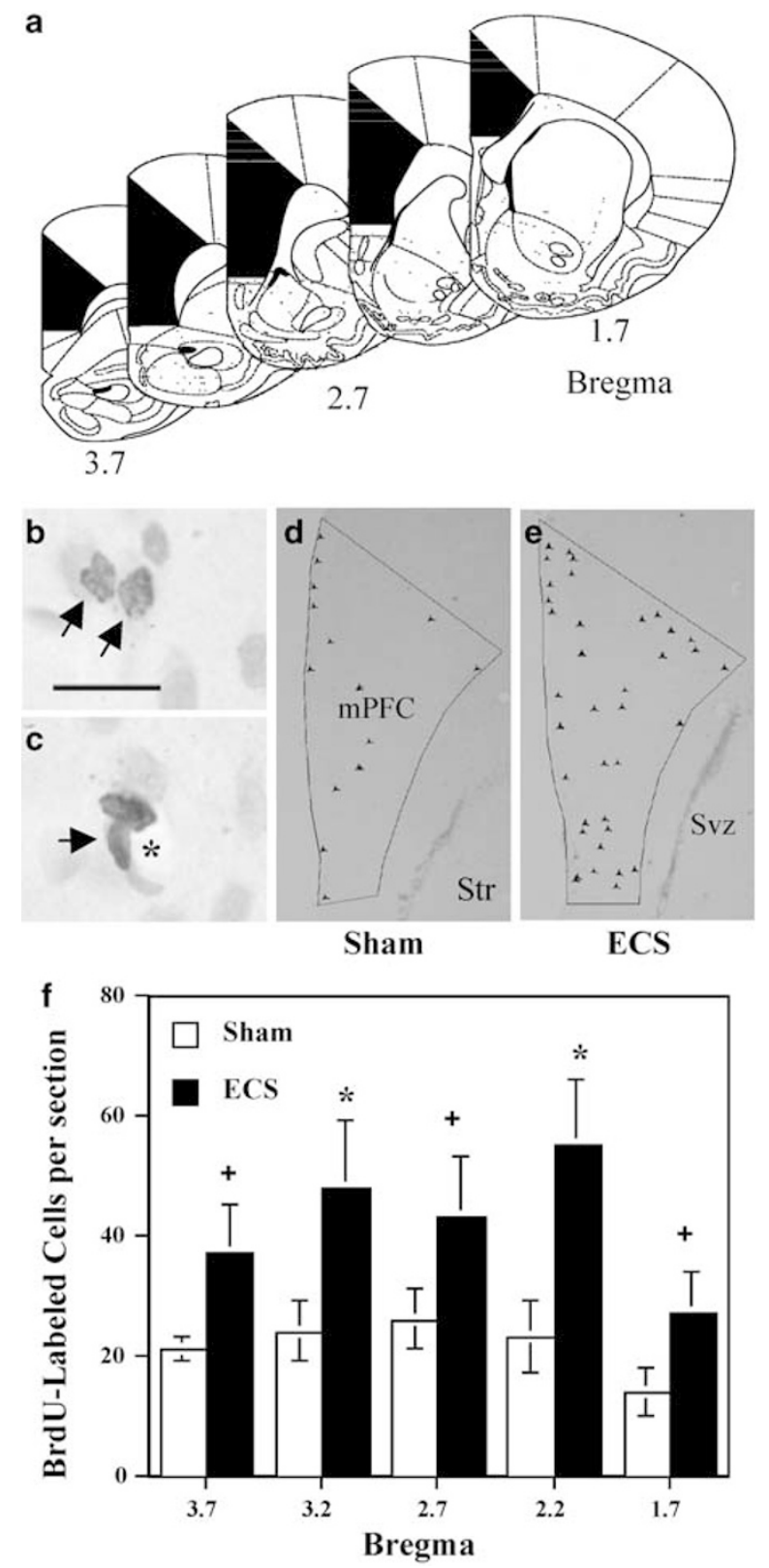

Figure I Analysis of BrdU-labeled cells in the mPFC of rat. (a) Cortical regions of interest on series of plates from Paxinos and Watson (1998). The shaded area shows the contour of the MPFC, which was included in the area analyzed for the number of BrdU-labeled cells. (b) and (c) Highpower magnifications of BrdU-labeled cells. (b) A doublet of BrdU-labeled cells, which is commonly observed in the MPFC of both sham and ECS animals. The cells with the dark staining are positive for BrdU. The sections were counterstained with Fast Red. (c) A BrdU-labeled cell (arrow) lining a blood vessel (asterisk), which was also found in both sham and ECS mPFC. This suggests that this cell may be endothelial. The scale bar represents $20 \mu \mathrm{m}$. (d) and (e) Low-power BrdU-labeled sections of the mPFC, at approximately $2.2 \mathrm{~mm}$ from Bregma, from sham (d)- and repeated ECS (e)treated animals. The BrdU-labeled cells in each section are indicated with a cross. Line drawings showing the counting contour used and the location of the labeled cells are shown. (f) Number of labeled cells at each level examined. The number of labeled cells was determined by unbiased stereological counting as described in the methods. The mean \pm SEM of five different sections counted at the levels indicated in Figure I was determined for sham and ECS. The results are expressed as the number of BrdU-labeled cells per section, ${ }^{*} p<0.05,{ }^{\dagger}<0.10$, compared to sham (Student's t-test). 
between sampling sites. The number of sampling sites ranged from 46 to 55 for smaller contours (plates 7 and 11) and from 65 to 74 for large contours (plates 8, 9, and 10), and was identical for sham- and ECS-treated sections. The average thickness of slide-mounted sections was 12, and $2 \mu \mathrm{m}$ guard zones were used to exclude artifacts at tissue surfaces. The analysis was performed by an observer blinded to treatment group.

For the phenotypic analysis of BrdU-labeled cells, sections of mPFC were prepared from animals that had survived 28 days after administration of BrdU. Five sections were randomly selected from the caudal mPFC of sham ( $n=5$ animals) or ECS $(n=6$ animals) animals and subjected to double immunolabeling for BrdU and one of several cell phenotypic marker antibodies, including antiNeuN (neurons), anti-Rip (oligodendrocytes), anti-RECA (endothelial cells), anti-S100 $\beta$ (glia), and anti-GFAP (glia). For the analysis of double labeling, BrdU-positive cells were first identified and then colocalization of one of the fluorescent secondary antibodies was assessed by confocal microscopy (Zeiss, Thornwood, New York). Images were sampled through a Z-series multitrack mode with emission filters chosen to diminish bleedthrough of fluorescent probes. For every double-immunohistochemical staining (BrdU plus each cell phenotypic antibody), at least 50 cells for each animal were analyzed. We have used this approach in previous studies for the analysis of the phenotype of BrdU-labeled cells (Malberg et al, 2000).

\section{RESULTS}

BrdU-labeled cells were localized throughout all cortical layers of the $\mathrm{mPFC}$ defined by plates $7-11$, or coordinates $3.70-1.70 \mathrm{~mm}$ relative to Bregma of Paxinos and Watson (1998) (Figure 1a). The morphology of the BrdU-labeled nuclei varied considerably (Figures $1 \mathrm{~b}$ and $\mathrm{c}$ ). In some cases, the BrdU-labeled cells were crescent shaped and localized on the luminal side of the blood vessels, indicative of an endothelial cell phenotype (Figure 1c). BrdU-labeled cells were often observed in pairs, but not in clusters. The number of BrdU-labeled cells in the caudal two-thirds mPFC, which included infralimbic, dorsal peduncular, prelimbic, and cingulate cortex, was analyzed (shown in Figure 1a, from Paxinos and Watson, 1998). This region of the $\mathrm{mPFC}$ was chosen because unambiguously defined and consistent reference spaces within the cortex are available for analysis. Furthermore, this region of the mPFC overlaps with regions of the human frontal cortex where decreased numbers of glia have been reported in post-mortem brains of depressed patients (Ongur et al, 1998; Rajkowska et al, 1999; Cotter et al, 2001). BrdU-labeled cells were found throughout the mPFC and the number of labeled cells was increased by ECS treatment (Figure 1d and e).

The number of BrdU-labeled cells in the caudal mPFC was quantified using a modified unbiased stereology method and Stereo Investigator software (MicroBrightField, Williston, VT). BrdU-labeled cells in the reference space of each section were analyzed using a fractionator probe, which allows for a systematic and random sampling of labeled cells. The number of BrdU-labeled cells was nearly doubled after repeated ECS administration (10 ECS, once daily) relative to the sham-handled controls (Figures $1 \mathrm{f}$ and 2a). This effect was observed at every level of the mPFC. A preliminary quantiation of BrdU-labeled cells in a small reference space within rostral $\mathrm{mPFC}$ sections at approximately plate 5 was performed and revealed the same differences between groups that was determined at the caudal levels (data not shown). Furthermore, a qualitative assessment of rostral sections at other levels revealed BrdU labeling that appeared consistent with that at more caudal levels. Therefore, it is possible that the increases in BrdU labeling observed after ECS occurs in the rostral as well as the caudal mPFC.

The fractionator probe was designed to sample $50 \%$ of the mPFC within the contour, and the BrdU-labeled cell counts per bilateral section were $22 \pm 4$ for sham- and $42 \pm 10$ for ECS-treated $(P<0.05$, Student's $t$-test). On a per area basis, the number of BrdU-labeled cells was 14 and $28 \mathrm{cells} / \mathrm{mm}^{2}$, respectively. It is also interesting to estimate the total number of newborn cells in the entire three-dimensional area of the mPFC. The number of cells per section can be estimated by doubling the number obtained using the fractionator probe (ie one half of the total area is counted according to the recommended sampling approach). This gives approximately 44 cells per section $(2 \times 22$ cells $)$ for the sham and 84 for ECS. Since every 10th section is analyzed throughout the mPFC, which extends over 40 sections ( $40 \mu \mathrm{m}$ each), the total number of cells is $44 \times 40$ or 1760 cells per bilateral mPFC. In the ECS-treated brains, the total number of cells is $84 \times 40$ or 3360 BrdU-labeled cells per bilateral mPFC. This is probably an underestimate of the total number of BrdU-labeled cells due to the lower number of counts obtained when the counting frames are at the edges of the contour and the fact that there is no correction for labeled cells, which were not counted on the face of each section.

To examine the phenotype of the newborn cells, the animals were killed 4 weeks after BrdU treatment. At this time point, the BrdU-labeled cells have differentiated into relatively mature cell types that can be identified by double labeling with phenotypic markers. At this 4 -week survival time, the cells were distributed in the same pattern as observed at the early time point $(2 \mathrm{~h})$, with labeled cells in all layers of the frontal cortex. To determine the cell phenotype more than 50 BrdU-labeled cells per animal were analyzed for colabeling of a second cellular marker. For analysis of neurons, colocalization of the neuronal nuclear marker, NeuN, was determined (Mullen et al, 1992). We did not observe colocalization of BrdU and NeuN in any of the cells examined. However, the BrdU- and the NeuN-labeled cells were often found in close proximity to each other, and were even touching in many cases (Figure 3a). In some cases, the BrdU-labeled cell nuclei were adjacent to the NeuN-labeled cell, giving it the appearance of a satellite cell as reported previously (Kornack and Rakic, 2001). This pattern of BrdU and NeuN staining was the same in both the sham- and ECS-treated rats.

To examine the cellular phenotype of the BrdU-labeled cell sections from both sham- and ECS-treated rats were double stained with antibodies against two different markers for astrocytes, GFAP (not shown), or $\mathrm{S} 100 \beta$ (Figure 3a). We failed to observe any cells that were immunopositive for both BrdU and one of these markers in 
either sham- or ECS-treated animals, indicating that the dividing cells in the frontal cortex do not differentiate into astrocytes.

The possibility that the newborn cells mature into oligodendrocytes was examined by double immunolabeling with Rip, an antibody previously characterized to stain developing as well mature oligodendrocytes (Friedman $e t$ al, 1989; Jhaveri et al, 1992). Double fluorescent immunohistochemistry revealed colocalization of anti-Rip labeling with BrdU-labeled cells. Analysis of the number of doublelabeled cells demonstrates that approximately $40 \%$ of the BrdU-labeled cells are also immunopositive for Rip in the mPFC (see Figures $2 b$ and $3 b-d$ ). The fraction of BrdUlabeled cells colabeled with Rip did not change with the ECS treatment. This indicates that ECS treatment results in an increase in the number of Rip-immunopositive cells in the frontal cortex.

Double immunohistochemistry with RECA-1, an antibody that recognizes rat endothelial cells that form the inner layer of a vascular wall, was conducted next. Colocalization of this cell marker with BrdU was also observed. The RECA-1/ BrdU-double-positive cells were characterized by a crescent-shaped nucleus (Figure $3 e$ and $\mathrm{f}$ ). The percent of BrdU and RECA-1 colabeled cells was approximately $20 \%$ (Figure 2b). This ratio was not influenced by ECS treatment, indicating that there is also an increase in the number of endothelial cells.

\section{DISCUSSION}

In this report, we show that cell proliferation in the frontal cortex is a dynamic process, subject to regulation by repeated ECS treatment. We show that after repeated electroconvulsive administration, the number of BrdUlabeled cells is markedly increased in the frontal cortex. Analysis of cell phenotype demonstrates that none of the newly formed cells differentiates and matures into neurons in either the sham- or ECS-treated groups. However, approximately $40 \%$ of the BrdU-labeled cells in the frontal cortex were immunopositive for an oligodendrocyte marker, Rip, 4 weeks after the BrdU injections. Further, approximately $20 \%$ of the BrdU-positive cells were colabeled with a marker for endothelial cells, RECA-1. The fraction of cells that differentiated into these cellular phenotypes was not influenced by ECS treatment.

Proliferation of cells in the adult brain has been intensely studied and debated. Neurogenesis in two proliferative zones, the SGZ and the SVZ, is well documented and accepted. In addition, there are reports that even under normal conditions, there is ongoing neurogenesis in the neocortex (Gould et al, 1999, 2001). In the present study, we found no evidence of neurogenesis in the area of the frontal cortex that was examined. A large number of the cells that we observed did have the appearance of 'satellite' cells: the cell bodies were closely apposed to a NeuN-labeled cell. Inspection of the Z-series sections of the confocal images invariably showed that the BrdU-labeled nucleus and the nucleus of the NeuN-labeled neuron were different. Our results with regard to adult neurogenesis in the frontal cortex are in agreement with earlier work by Korr et al (1973) and recent work by Kornack and Rakic (2001). These
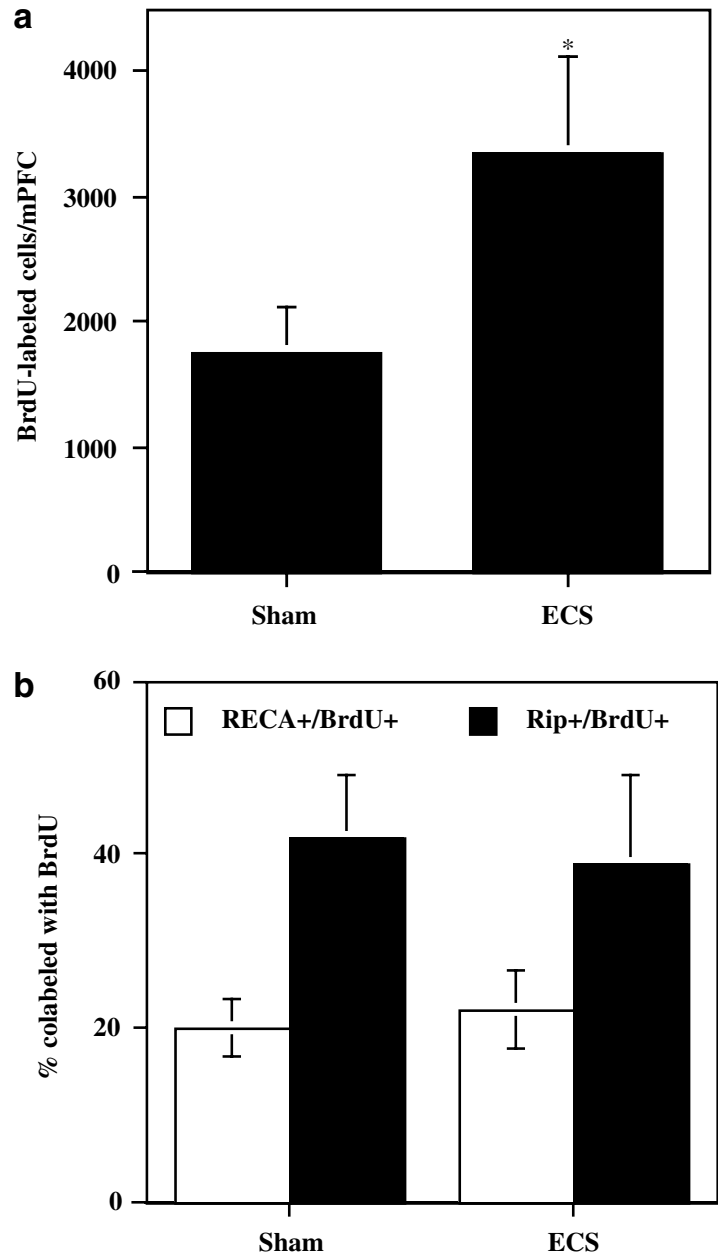

Figure 2 Repeated ECS increases the number of BrdU-labeled cells in the mPFC. (a) Number of BrdU-labeled cells in the mPFC of sham- and ECS-treated animals. The number of labeled cells was determined by unbiased stereological counting as described in the methods. The mean \pm SEM of five different sections counted at the levels indicated in Figure I was determined to give a group average for sham and ECS. The results are expressed as the number of BrdU-labeled cells per prefrontal cortex, $* p<0.05$ compared to sham (Student's t-test). (b) Percent of cells displaying different phenotypic markers. The phenotype of the BrdUlabeled cells was determined by colocalization of cellular markers from oligodendrocytes (Rip) or endothelial cells (RECA-I). At least $50 \mathrm{BrdU}$ labeled cells per animal were analyzed for double labeling. The results are expressed as the percent of the total number of BrdU-labeled cells and are the mean \pm SEM of five to six separate animals. There was no difference in the percent of double-labeled cells between the sham- and ECS-treated animals.

reports, using different S-phase markers, failed to show the presence of labeled neurons in cortical areas of mice and monkeys. Furthermore, a recent study by Koketsu et al (2003), which studied the proliferation and differentiation of adult-generated cells in two species of monkey, found no evidence for neocortical neurogenesis.

All regions of the mammalian brain are reported to harbor progenitor cells with a capability to differentiate into neurons when exposed to proper cues (Palmer et al, 1995). In the current study, we found that repeated seizure treatment is not sufficient to induce maturation and differentiation of these cells into neurons in the frontal cortex. Interestingly, stimuli or insults, which are 

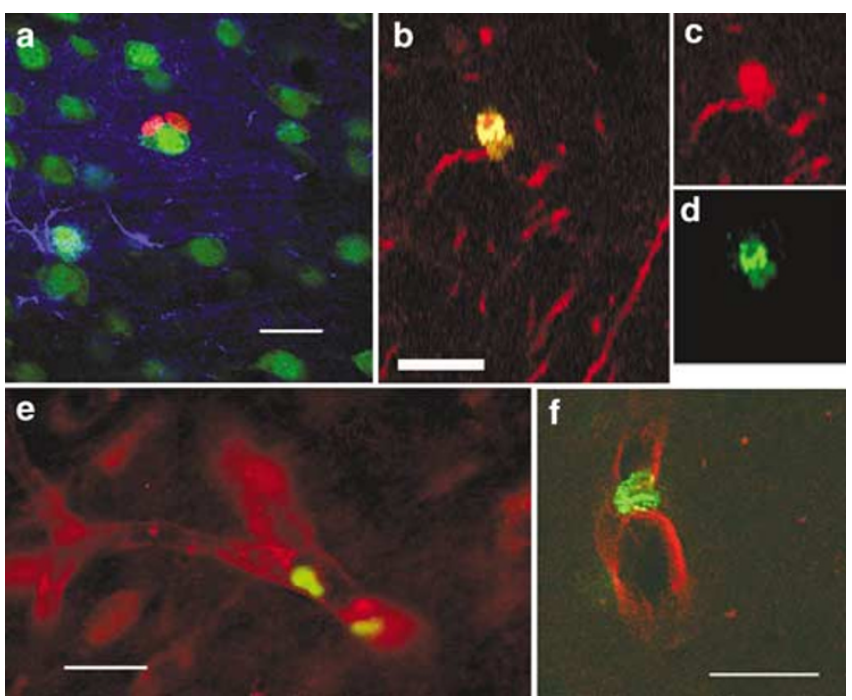

Figure 3 Colocalization of BrdU-labeled cells with different cellular markers in the frontal cortex. (a) A confocal micrograph of a triple immunostained section of frontal cortex from an ECS-treated rat. The section has been immunostained for NeuN (green), a neuronal marker, $\mathrm{BrdU}$ (red), a marker for proliferation, and $\mathrm{SI} 00 \beta$, a glial cell marker (blue). Two BrdU-labeled nuclei are located close to the NeuN-positive neuron, but there is no colocalization of the labeling. (b-d) Confocal immunohistochemical images of BrdU (green) and Rip (red), an oligodendrocyte marker. (b) A merged image of a cell double-labeled with Rip and BrdU (yellow). (c) and (d) Single channel images for either Rip (c) or BrdU (d) for the same cell. (e) and ( $f$ ). Double labeling with the endothelial cell marker, RECA-I (red), and BrdU (green). (e) A photomicrograph showing the location of the BrdU-labeled endothelial cell in the vessel wall. ( $f$ ) A confocal micrograph showing a BrdU-labeled cell (green) lining the vessel wall, which is stained with RECA-I (red). Scale bar in all is $20 \mu \mathrm{m}$.

accompanied by cell death, have been reported to induce neurogenesis outside of the neurogenic zones, including in the cerebral cortex (Arvidsson et al, 2002; Magavi et al, 2000). There is no evidence that repeated ECS treatment increases cell death or causes cell damage (Madsen et al, 2000; Vaidya et al, 1999) and this could explain why there is no evidence of neurogenesis in the frontal cortex in the current study.

The dividing cells in the frontal cortex did not differentiate into cells with an astrocytic phenotype at the 4-week time point (ie there was no colocalization of BrdU with GFAP). This result is in line with the data from Koketsu et al (2003), who observe less than $1 \%$ of the BrdUlabeled cells in the cortex colabeled with GFAP. Glial cells outnumber the neurons in the CNS by about 10:1, and take part in a number of processes that are critical for the proper function of neurons, such as growth factor synthesis, neurotransmitter removal, and metabolic support. In this report, we show that oligodendrocytes are generated in the frontal cortex of adult rat. The role of the renewal of oligodendrocytes in the frontal cortex is presently unclear but has been observed to increase after cortical lesions (Ludwin, 1984) and, in this study, after seizures.

As is the case for oligodendrocytes, endothelial cell proliferation in the brain has been documented previously (Korr et al, 1973; Mares and Bruckner, 1978). The fraction of BrdU-labeled cells with an endothelial phenotype was constant in the two groups. In the dentate gyrus, endothelial cell proliferation is thought to occur in conjunction with proliferation of neuronal precursors, and the presence of 'a vascular niche' for neurogenesis has been hypothesized (Palmer et al, 2000). In the frontal cortex, there was no obvious association between the endothelial cells and the other BrdU-labeled cells, indicating that the vascular supply required for cell proliferation in this region is sufficient. Since this manuscript was submitted, other laboratories have demonstrated that ECS increases the number of endothelial cells and NG-2 positive/oligodendrocytes in the hippocampus (Wennström et al, 2003; Hellsten et al, 2004) and NG-2/oligodendrocytes in the amygdala (Wennström et al, 2004). It is unclear which growth factors are responsible for the increased proliferation in the frontal cortex after seizures. BDNF, which has been shown to induce proliferation and neurogenesis in regions outside of the main neurogenic zones of the brain, is dramatically increased in the frontal cortex, as well as the hippocampus (Nibuya et al, 1995). Other growth factors such as FGF-2, which is increased after seizures, might also be involved (Gwinn et al, 2002).

Studies of human brains by analysis of post-mortem tissue or by in vivo magnetic resonance imaging of living patients indicate that there are morphological alterations in the frontal cortex of patients with mood disorders. The post-mortem studies suggest that mood disorders are characterized by specific and discrete decreases in the number of glia, as well as the size of neuronal cell bodies in specific regions of the frontal cortex (Ongur et al, 1998; Rajkowska et al, 1999; Cotter et al, 2001). It is difficult to assess the overlap between the region of the frontal cortex analyzed in the present study in rat brain with the regions analyzed in the post-mortem studies, but it is likely that there is at least some commonality. It is likely that the area analyzed includes at least in part the subgenual prefrontal cortex and cingulate cortex analyzed in two of the postmortem studies (Ongur et al, 1998; Cotter et al, 2001). The degree to which glial cell loss contributes to the total volume change in the frontal cortex of depressive patients has not been clarified, and it is possible that a reduction in neuronal cell body size and loss of neurites also contribute to the decreased volume. In addition, these studies have not identified which types of glial cells are decreased in mood disorders, and existing data suggest that both astrocytes and oligodendrocytes are influenced (Rajkowska, 2002).

In summary, the results of the present study demonstrate that repeated ECS treatment increases the number of proliferating glia in rat frontal cortex. The phenotype of approximately $60 \%$ of newborn cells in the frontal cortex has been identified as oligodendrocytes or endothelial cells. There was no evidence of neurogenesis in this brain region in either sham- or ECS-treated animals. The upregulation of glia in response to ECS treatment could serve to reverse the atrophy and loss of cells that has been observed in depressed patients. In addition, the induction of endothelial cells by ECS treatment could indicate that there are also changes in blood vessel structure and integrity that could contribute to the actions of ECS. Additional studies will be needed to identify the growth/proliferation factors responsible for ECS induction of these cells, and to characterize their function in cellular and behavioral models of depression. 


\section{ACKNOWLEDGEMENTS}

This work is supported by USPHS Grants MH45481 and 2 PO1 MH25642, a Veterans Administration National Center Grant for PTSD, and by the Connecticut Mental Health Center. TMM is supported by a grant from the Danish MRC.

\section{REFERENCES}

Arvidsson A, Collin T, Kirik D, Kokaia Z, Lindvall O (2002). Neuronal replacement from endogenous precursors in the adult brain after stroke. Nat Med 8: 963-970.

Bremner JD, Staib LH, Kaloupek D, Southwick SM, Soufer R, Charney DS (1999). Neural correlates of exposure to traumatic pictures and sound in Vietnam combat veterans with and without posttraumatic stress disorder: a positron emission tomography study. Biol Psychiatry 45: 806-816.

Chen A-H, Shin K, Duman RS, Sanacora G (2001). ECS-Induced mossy fiber sprouting and BDNF expression are attenuated by ketamine pretreatment. J ECT 17: 27-32.

Cotter D, Mackay D, Landau S, Kerwin R, Everall I (2001). Reduced glial cell density and neuronal size in the anterior cingulate cortex in major depressive disorder. Arch Gen Psychiatry 58: 545-553.

Coyle JT, Schwarcz R (2000). Mind glue: implications of glial cell biology for psychiatry. Arch Gen Psychiatry 57: 90-93.

Drevets WC, Price JL, Simpson JR, Todd RD, Reich T, Vannier M et al (1997). Subgenual prefrontal cortex abnormalities in mood disorders. Nature 386: 824-827.

Duivestijn AM, van Goor H, Klatter F, Majoor GD, van Bussel E, van Breda Vriesman JC (1992). Antibodies defining rat endothelial cells: RECA-1, a pan-endothelial cell-specific monoclonal antibody. Lab Invest 66: 459-466.

Duman RS, Malberg J, Nakagawa S (2001). Regulation of adult neurogenesis by psychotropic drugs and stress. J Pharmacol Exp Ther 299: 401-407.

Friedman B, Hockfield S, Black JA, Woodruff KA, Waxman SG (1989). In situ demonstration of mature oligodendrocytes and their processes: an immunocytochemical study with a new monoclonal antibody, rip. Glia 2: 380-390.

Gould E, Reeves AJ, Graziano MS, Gross CG (1999). Neurogenesis in the neocortex of adult primates. Science 286: 548-552.

Gould E, Tanapat P, McEwen BS, Flugge G, Fuchs E (1998). Proliferation of granule cell precursors in the dentate gyrus of adult monkeys is diminished by stress. Proc Natl Acad Sci USA 95: $3168-3171$.

Gould E, Vail N, Wagers M, Gross CG (2001). Adult-generated hippocampal and neocortical neurons in macaques have a transient existence. Proc Natl Acad Sci USA 98: 10910-10917.

Gwinn RP, Kondratyev A, Gale K (2002). Time-dependent increase in basic fibroblast growth factor protein in limbic regions following electroshock seizures. Neuroscience 114: 403-409.

Hellsten J, Wennström M, Bengzon J, Mohapel P, Tingström A (2004). Electroconvulsive seizures induce endothelial cell proliferation in adult rat hippocampus. Biol Psychiatry 55: 420-427.

Jacobs BL, Praag H, Gage FH (2000). Adult brain neurogenesis and psychiatry: a novel theory of depression. Mol Psychiatry 5: 262-269.

Jhaveri S, Erzurumlu RS, Friedman B, Schneider GE (1992). Oligodendrocytes and myelin formation along the optic tract of the developing hamster: an immunohistochemical study using the Rip antibody. Glia 6: 138-148.

Kempermann G, Kuhn HG, Gage FH (1997). Genetic influence on neurogenesis in the dentate gyrus of adult mice. Proc Natl Acad Sci USA 94: 10409-10414.
Koketsu D, Mikami A, Miyamoto Y, Hisatsune T (2003). Nonrenewal of neurons in the cerebral neocortex of adult macaque monkeys. J Neurosci 23: 937-942.

Kornack DR, Rakic P (2001). Cell proliferation without neurogenesis in adult primate neocortex. Science 294: 2127-2130.

Korr H, Schultze B, Maurer W (1973). Autoradiographic investigations of glial proliferation in the brain of adult mice. I. The DNA synthesis phase of neuroglia and endothelial cells. J Comp Neurol 150: $169-175$.

Ludwin SK (1984). Proliferation of mature oligodendrocytes after trauma to the central nervous system. Nature 308: 274-275.

Madsen TM, Treschow A, Bengzon J, Bolwig TG, Lindvall O, Tingstrom A (2000). Increased neurogenesis in a model of electroconvulsive therapy. Biol Psychiatry 47: 1043-1049.

Magavi SS, Leavitt BR, Macklis JD (2000). Induction of neurogenesis in the neocortex of adult mice. Nature 405: 951-955.

Malberg JE, Eisch AJ, Nestler EJ, Duman RS (2000). Chronic antidepressant treatment increases neurogenesis in adult rat hippocampus. J Neurosci 20: 9104-9110.

Manji HK, Drevets WC, Charney DS (2001). The cellular neurobiology of depression. Nat Med 7: 541-547.

Mares V, Bruckner G (1978). Postnatal formation of non-neuronal cells in the rat occipital cerebrum: an autoradiographic study of the time and space pattern of cell division. J Comp Neurol 177: 519-528.

Markakis EA, Gage FH (1999). Adult-generated neurons in the dentate gyrus send axonal projections to field CA3 and are surrounded by synaptic vesicles. J Comp Neurol 406: 449-460.

Mullen RJ, Buck CR, Smith AM (1992). NeuN, a neuronal specific nuclear protein in vertebrates. Development 116: 201-211.

Nestler EJ, Barrot M, Dileone RJ, Eisch AJ, Gold SJ, Monteggia L (2002). Neurobiology of depression. Neuron 34: 13-25.

Nibuya M, Morinobu M, Duman RS (1995). Regulation of BDNF and trkB mRNA in rat brain by chronic electroconvulsive seizure and antidepressant drug treatments. J Neurosci 15: 7539-7547.

Ongur D, Drevets WC, Price JL (1998). Glial reduction in the subgenual prefrontal cortex in mood disorders. Proc Natl Acad Sci USA 95: 13290-13295.

Palmer TD, Ray J, Gage FH (1995). FGF-2-responsive neuronal progenitors reside in proliferative and quiescent regions of the adult rodent brain. Mol Cell Neurosci 6: 474-486.

Palmer TD, Willhoite AR, Gage FH (2000). Vascular niche for adult hippocampal neurogenesis. J Comp Neurol 425: 479-494.

Paxinos G, Watson C (1998). The Rat Brain in Stereotactic Coordinates Fourth Edition. Academic Press Australia: Sydney.

Pencea V, Bingaman KD, Wiegand SJ, Luskin MB (2001). Infusion of brain-derived neurotrophic factor into the lateral ventricle of the adult rat leads to new neurons in the parenchyma of the striatum, septum, thalamus, and hypothalamus. J Neurosci 21 : 6706-6717.

Rajkowska G (2002). Cell pathology in bipolar disorder. Bipolar Disord 4: 105-116.

Rajkowska G, Miguel-Hidalgo JJ, Wei J, Dilley G, Pittman SD, Meltzer HY et al (1999). Morphometric evidence for neuronal and glial prefrontal cell pathology in major depression. Biol Psychiatry 45: 1085-1098.

Scott BW, Wojtowicz JM, Burnham WM (2000). Neurogenesis in the dentate gyrus of the rat following electroconvulsive shock seizures. Exp Neurol 165: 231-236.

Sheline YI, Sanghavi M, Mintun MA, Gado MH (1999). Depression duration but not age predicts hippocampal volume loss in medically healthy women with recurrent major depression. $J$ Neurosci 19: 5034-5043.

Uylings HBM, Groenewegen HJ, Kolb B (2003). Do rats have a prefrontal cortex? Behav Brain Res 146: 3-17. 
Vaidya VA, Siuciak JA, Du F, Duman RS (1999). Hippocampal mossy fiber sprouting induced by chronic electroconvulsive seizures. Neuroscience 89: 157-166.

Van Eden CG, Uylings HBM (1985). Cytoarchitectonic development of the prefrontal cortex in the rat. J Comp Neurol 241: 253-267.

van Praag H, Kempermann G, Gage FH (1999). Running increases cell proliferation and neurogenesis in the adult mouse dentate gyrus [see comments]. Nat Neurosci 2: 266-270.

van Praag H, Schinder AF, Christie BR, Toni N, Palmer TD, Gage FH (2002). Functional neurogenesis in the adult hippocampus. Nature 415: 1030-1034.

Wennström M, Hellsten J, Tingström A (2004). Electroconvulsive seizures induce proliferation of NG-2-expressing glial cells in adult rat amygdala. Biol Psych 55: 464-471.

Wennström M, Hellsten J, Ekdahl CT, Tingström A (2003). Electroconvulsive seizures induce proliferation of NG-2-expressing glial cells in adult rat hippocampus. Biol Psychiatry 54: 1015-1024. 